\title{
Time to Burn: Modeling Wildland Arson as an Autoregressive Crime Function
}

\author{
Jeffrey P. Prestemon and David T. Butry
}

\begin{abstract}
Six Poisson autoregressive models of order $p[\operatorname{PAR}(p)]$ of daily wildland arson ignition counts are estimated for five locations in Florida (1994-2001). In addition, a fixed effects time-series Poisson model of annual arson counts is estimated for all Florida counties (1995-2001). PAR $(p)$ model estimates reveal highly significant arson ignition autocorrelation, lasting up to eleven days, in addition to seasonality and links to law enforcement, wildland management, historical fire, and weather. The annual fixed effects model replicates many findings of the daily models but also detects the influence of wages and poverty on arson, in ways expected from theory. All findings support an economic model of crime.
\end{abstract}

Key words: autoregressive, crime, firesetting, Poisson, police, poverty, wages.

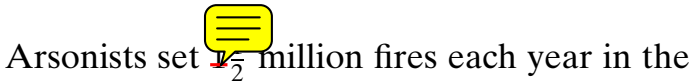
United States, resulting in over $\$ 3$ billion in damages, 500 fatalities, and thousands of injuries (TriData Corporation). From the standpoint of wildfire, arson comprises a significant share of all wildland fires in many parts of the country, especially in populated regions. Hall reports that about $10 \%$ of property lost to fire is attributable to outdoor firesetting. Arson wildfires adversely affect wildland management of timber, water, recreation, grazing, and biodiversity.

Wildland arson threatens lives and the stability of the communities that depend on land-based social goods and services. The arson-ignited 2002 Hayman fire, near Denver, burned 138,000 acres, destroyed over 100 residences, and generated damages and costs for governments that totaled over $\$ 100$ million. Evacuations and other disruptions created further economic losses and transfers that totaled into the tens of millions of dollars (Kent et al.). Although research is limited on the causal factors for wildland arson, preliminary evidence suggests that arson wildfires may cause a dis-
\end{abstract}

\footnotetext{
Jeffrey P. Prestemon, research forester, and David T. Butry, economist, are with the Southern Research Station of the USDA Forest Service, Research Triangle Park, North Carolina.

The authors thank Paul Woodard of the University of Alberta, Edmonton; Patrick T. Brandt of the University of North Texas; Karen L. Abt of the Southern Research Station of the USDA Forest Service; journal editor Stephen K. Swallow; and three anonymous journal reviewers for many helpful comments throughout the review process. Finally, the authors recognize partial funding for this research that was provided by the Joint Fire Science Program and the National Fire Plan.
}

proportionate share of losses and costs because they are more commonly ignited near values at risk (Butry, Pye, and Prestemon).

In spite of its potential importance, research into the factors influencing wildland arson has been limited to only a few published studies (e.g., Donoghue and Main). This contrasts with a more abundant and recent literature on property crime. For example, rural and urban property crime has been linked to economic conditions, including poverty (Arthur; Brotman and Fox; Hannon; Hershbarger and Miller; Neustrom and Norton), unemployment and wages (Carlson and Michalowski; Burdett, Lagos, and Wright; Gould, Weinberg, and Mustard; Spillman and Zak), and race (Viscusi). A new body of research has connected crime to law enforcement effort (Cameron; Corman and Mocan; Di Tella and Schargrodsky; Eck and Maguire; Fisher and Nagin; Marvell and Moody).

Potentially more important than the limited research linking arson to hypothesized causes, wildland arson has not been analyzed as a temporal process. This is in spite of colloquial knowledge of its temporal clustering and in spite of research that has identified clustering and seasonality for other kinds of crimes (e.g., Farrell and Pease; Johnson and Bowers; Bowers and Johnson; Surrette; Townsley and Pease; Townsley, Homel, and Chaseling). One reason for a lack of progress in capturing temporal clustering is that only recently have valid statistical approaches been developed that can account for it in event models (e.g., Chang, Kavvas, and Delleur; Zeger; Harvey 
and Fernandes; Cameron and Trivedi; Brandt et al.; Brandt and Williams 2001).

The correct specification of an event count model (see Cameron and Trivedi) that includes an underlying autoregressive data generation process for daily wildland arson ignitions would be justified for statistical, as well as behavioral, reasons (see Brandt and Williams 2001). Statistical consistency, unbiasedness, and efficiency objectives of count modeling require explicit accounting for autoregressivity (Brandt and Williams 2001). Structure arsonists often set multiple fires in a short time frame (Sapp et al.), leading to a hypothesis that wildland arsonists demonstrate the same tendency. Also, youth-caused property crime has been shown to include "copycat" elements (Surrette), so wildland arsonists might be prone to this behavior, as well. Augmenting both serial and copycat phenomena is the informational content of recent arson fires: arsonists could view a successful wildland arson ignition as a signal that environmental conditions are favorable for successfully starting new fires, a plausible encouragement for more. ${ }^{1}$

The primary goal of this research is to model wildland arson to account for temporal clustering and in order to test theories in both criminology and wildland management. We estimate two kinds of count data models using county-level data in Florida. The first is a Poisson autoregressive model of order $p$ (Brandt et al.; Brandt and Williams 2001) of daily wildland arson ignitions. This model tests the hypothesis that arson is temporally clustered into multiple-day outbreaks. The second is a fixed-effects panel Poisson model of annual wildland arson ignitions for all Florida counties. Although this model cannot capture fine time-scale clustering, it introduces annual variation in wildland arson that may better account for how arson is affected by variables that change slowly or that cannot be expressed accurately at the daily time scale.

\footnotetext{
${ }^{1}$ Alternatively, autoregressive patterns in wildland arson are only due to environmental factors that are not observable by the analyst or that capture imprecision at finer spatial or temporal scales. In other words, arson ignition attempts could occur at a constant rate throughout a year, but it is only during certain weather that ignitions are successful. Lagged ignitions might then proxy for the unobservable local weather. If this is the case, then our modeling addresses successful arson ignitions, not arson attempts.
}

\section{Conceptual Framework}

Becker specified person $i$ 's decision on the commission of a crime as

$$
O_{i}=O_{i}\left(\pi_{i}, f_{i}, u_{i}\right)
$$

where $\pi_{i}$ is the probability of being caught and convicted, $f_{i}$ is an income-equivalent loss experienced by the offender for being caught and convicted, and $u_{i}$ measures all the other influences on the offense. Equation (1) can be called a crime function (Fisher and Nagin). The first derivatives of $O_{i}$ with respect to $\pi_{i}$ and $f_{i}$ are negative.

Now, define the arsonist's psychic and income benefits from illegal firesetting as $g_{i}$ and the production cost for the firesetting as $c_{i}$. As described by Burdett, Lagos, and Wright, and ignoring issues of risk aversion, the loss from being caught and convicted of committing the crime, $f_{i}$, is a positive function of income while employed, so that $f_{i}=f_{i}\left(w_{i}, W_{i}\right)$, where $w_{i}$ is the wage rate (Gould, Weinberg, and Mustard) and $W_{i}$ is the employment status. Adapting Becker (footnote 16), the prospective arsonist's expected utility from successfully starting a wildland arson fire may be expressed as

$$
\begin{aligned}
E U_{i}\left(O_{i}\right)= & \pi_{i} U_{i}\left(g_{i}-c_{i}-f_{i}(W, w)\right) \\
& +\left(1-\pi_{i}\right) U_{i}\left(g_{i}-c_{i}\right) .
\end{aligned}
$$

As wages rise, for example, the expected net utility from arson declines, lowering the probability that an arson fire will be set: $\partial E U_{i}\left(O_{i}\right) /$ $\partial w_{i}=\pi\left(\partial E U_{i} / \partial f_{i}\right)\left(\partial f_{i} / \partial w_{i}\right)<0 .^{2}$

As with opportunity costs, the production costs of firesetting can be more elaborately described. For example, $c_{i}$ may be a function of time available (Jacob and Lefgren); fuels and weather (Gill et al., Vega Garcia et al., Prestemon et al.); whether the person is unemployed (creating a lower opportunity cost of crime); and information

\footnotetext{
${ }^{2}$ The marginal utility of committing arson would be larger if the opportunity cost of work were included as an additional cost. Assuming that $c_{i}=c_{i}\left(w_{i}\right)$, and $\partial c_{i}\left(w_{i}\right) / \partial w_{i}>0$, then $\partial E U_{i}\left(O_{i}\right) / \partial w_{i}$ $=\pi\left(\partial E U_{i} / \partial f_{i}\right)\left(\partial f_{i} / \partial w_{i}\right)+\left(\partial E U_{i} / \partial c_{i}\right)\left(\partial c_{i} / \partial w_{i}\right)<0$. Because the second term on the right-hand side of this expression is also negative, the marginal effect of a wage increase on utility is even larger than if the opportunity cost of time to commit the arson crime is 0 .
} 
on other successfully ignited arson wildfires, which lowers the production cost by raising the success rate. ${ }^{3}$ Anything that raises the crime production cost, lowers the expected utility of the crime: $\partial E U_{i}\left(O_{i}\right) /$ $\partial c_{i}=\pi\left(\partial U_{i} / \partial c_{i}\right)+(1-\pi)\left(\partial U_{i} / \partial c_{i}\right)<0$.

Similarly, following Burdett, Lagos, and Wright, $\pi$ can be expressed as a function of law enforcement effort. As Fisher and Nagin pointed out, aggregate crime may be simultaneously determined with law enforcement, so not accounting for this simultaneity when it is present can cause a positive bias in a measured statistical effect of law enforcement on crime (Cameron; Marvell and Moody; Eck and Maguire). Becker describes how law enforcement effort (spending) to reduce crime is jointly determined with the crime rate. Recent research has used instrumental variables methods to resolve this problem in estimating crime functions. In any case, it is likely that bureaucratic delays would mean that law enforcement agencies would find it difficult to quickly change enforcement rates in response to higher crime rates. There is a lag between hiring new officers and effectiveness of the new officers in the field (Corman and Mocan). ${ }^{4}$ Gould, Weinberg, and Mustard showed that the kind of endogeneity involved with one measure of law enforcement (police presence or spending) is small. We contend that aggregate law enforcement is unlikely to change in response to wildland arson, given that most crime is not wildland arson. We therefore believe that assuming exogeneity is justified. $^{5}$

\footnotetext{
${ }^{3}$ Alternatively, Burdett, Lagos, and Wright describe $\pi$ as the probability of being caught, conditional on having an opportunity to commit a crime. Following this, weather and fuels could provide the opportunity, so that $\pi$ should be a function of law enforcement, weather, and fuels. In our empirical specification, this difference is not important.

${ }^{4}$ An ideal model would instrument $E$ before including it in the model as a contemporaneous predicted variable, but the available "best" instruments for $E$ at the county level or at the twocounty level using daily data are limited or unavailable. We also attempted to control for simultaneity by directly including an instrument in our annual model-a measure of so-called "index crime" (Florida Department of Law Enforcement 2004) —and found no large effects on parameter estimates or significances. Although Gould, Weinberg, and Mustard did not find that the bias affected significance or direction of effect of many other predictors of crime, some doubt remains and suggests an avenue for additional research.

${ }^{5}$ In pooled time-series cross-sectional data on annual arson ignitions for all 67 Florida counties, 1995-2001, wildland arson ignitions per capita and police per capita are negatively correlated $(r=-0.14)$. This contrasts with the positive correlation between the crime index (Florida Department of Law Enforcement 2004) and police per capita $(+0.29)$, providing some evidence of joint
}

\section{Empirical Specifications}

\section{A PAR(p) Model of Daily Wildland Arson Ignitions}

The $\operatorname{PAR}(p)$ model, generalizing work by Grunwald, Hamza, and Hyndman, was originally developed by Brandt and Williams (2001) to model persistence in annual patterns of presidential vetoes and purse snatchings. In our application to daily data, we start by summing the daily decisions on crime made by all persons $(i=1$ to $I)$ in location $j$. The aggregate arson fire outcome of these $I$ decisions on day $t$ in location $j$ is a count of arson ignitions, $y_{j, t}$. The $\operatorname{PAR}(p)$ model hypothesizes that the observed count is drawn from a Poisson distribution conditional on $m_{j, t}$,

$$
\operatorname{Pr}\left[y_{j, t} \mid m_{j, t}\right]=\frac{m_{j, t}^{y_{j, t}} e^{-m_{j, t}}}{y_{j, t} !}
$$

where $m_{j, t}=\mathrm{E}\left[y_{j, t} \mid Y_{j, t}\right]$ is the conditional mean of a linear $\operatorname{AR}(p)$ process. The expected count can be described as

$$
\begin{aligned}
\mathrm{E}\left[y_{j, t} \mid Y_{j, t-1}\right]= & \sum_{i=1}^{p} \boldsymbol{\rho}_{j, i} y_{j, t-i} \\
& +\left(1-\sum_{i=1}^{p} \boldsymbol{\rho}_{j, i}\right) \exp \left(\mathbf{x}_{j, t}^{\prime} \boldsymbol{\beta}_{j}\right)
\end{aligned}
$$

where $\mathbf{x}_{j, t}$ is a vector of independent variables (including a constant), $\boldsymbol{\beta}_{j}$ is a vector of associated parameters, and the $\rho_{j, i}$ 's are the autoregressive parameters.

The density of (5) has a gamma-distributed conjugate prior such that

$$
\operatorname{Pr}\left(m_{j, t} \mid Y_{j, t-1}\right)=\Gamma\left(\sigma_{j, t-1}^{2} m_{j, t-1}, \sigma_{j, t-1}^{2}\right)
$$

where $m_{j, t-1}$ and the variance $\sigma_{j, t-1}^{2}$ are both positive, $\Gamma(\cdot)$ is the gamma distribution, and $m_{j, t-1}=\mathrm{E}\left[y_{j, t} \mid Y_{j, t-1}\right]$ and $\sigma_{j, t-1}^{2}=V\left[y_{j, t} \mid\right.$ $\left.Y_{j, t-1}\right]$. The likelihood equation associated

determination, and the negative correlation between the crime index and wildland arson per capita $(-0.19)$, which is circumstantial evidence that law enforcement is exogenous to wildland arson ignitions. 
with this model is (omitting for simplicity the location subscript $j$ ):

(7)

$$
\begin{aligned}
\ell\left(m_{t-1}, \sigma_{t-1}^{2} \mid y_{t}, \ldots, y_{T} ; Y_{t-1}\right) \\
=\ln \prod_{t=1}^{T} \operatorname{Pr}\left(y_{t} \mid Y_{t}\right)=\sum_{t=1}^{T} \ln \Gamma\left(\sigma_{t-1}^{2} m_{t-1}+y_{t}\right) \\
\quad-\Gamma\left(y_{t}+1\right)-\Gamma\left(\sigma_{t-1}^{2} m_{t-1}\right) \\
\quad+\sigma_{t-1}^{2} m_{t-1} \ln \left(\sigma_{t-1}^{2}\right) \\
\quad-\left(\sigma_{t-1}^{2} m_{t-1}+y_{t}\right) \ln \left(1+\sigma_{t-1}^{2}\right) .
\end{aligned}
$$

The associated instantaneous (short-run) impact (marginal effect) of a change in variable $x_{k}$ in $\mathbf{x}$ on the count is described as

$$
\frac{\partial m_{j, t}}{\partial x_{j, k, t}}=\left(1-\sum_{i=1}^{p} \rho_{j, i}\right) \exp \left(\mathbf{x}_{j, t}^{\prime} \boldsymbol{\beta}_{j}\right) \beta_{j, k}
$$

The elasticity of the ignition count, at some reference point in the relationship between the count, and the variable in question corresponding with the impact, could be calculated simply by multiplying (8a) by $\left(\bar{x}_{j, k} / \bar{m}_{j}\right)$. Here, $\bar{x}_{j, k}$ and $\bar{m}_{j}$ could be the mean values for $x_{j, k}$ and $m_{j}$ observed in the data. The associated long-run impact of a change in variable $x_{k}$ in $\mathbf{x}$ on the count in location $j$ is described as

$$
\frac{\partial m_{j, t} / \partial x_{j, k, t}}{\left(1-\sum_{i=1}^{p} \rho_{j, i}\right)}=\exp \left(\mathbf{x}_{j, t}^{\prime} \beta_{j}\right) \beta_{j, k}
$$

and the elasticity would be calculable in a manner analogous to the instantaneous effect, i.e., $\exp \left(\mathbf{x}_{j, t}^{\prime} \boldsymbol{\beta}_{j}\right) \beta_{j, k} \bar{x}_{j, k} / \bar{m}_{j}$. Note, however, that the expected values of the estimated parameters in the $\operatorname{PAR}(p)$ model do not necessarily equal the expected values of the estimated corresponding parameters in the Poisson (unless all $\rho_{j, i}=$ $0)$. Brandt and Williams (2001) illustrate, per a Monte Carlo simulation, that if the process is truly a $\operatorname{PAR}(p)$ process, then a Poisson model will underestimate the true long-run impact.

Our daily arson ignition model is estimated for five high arson locations in Florida. These five are comprised of four two-county pairs (Duval-St. Johns, Flagler-Volusia, TaylorDixie, Sarasota-Charlotte) and one single county (Santa Rosa). The State of Florida identifies these as five homogeneous areas having the largest concentration of arson in the state. As long as our assumptions that behavioral or underlying relationships between dependent and independent variables hold statewide, this sample would be representative of aggregate arson behavior in Florida. Otherwise, our findings are strictly applicable just to the five locations. $^{6}$

The full specification of a daily arson crime function, consistent with Becker; Burdett, Lagos, and Wright; Gould, Weinberg, and Mustard; and Jacob and Lefgren, includes variables measuring law enforcement effort, economic conditions, fuels and fuels management, weather, and daily and seasonal factors. Hence, our model includes the location's daily interpolation of law enforcement effort, $E$ (i.e., $\pi_{t}=\pi\left(E_{t}\right)$ ); a daily interpolation of the percent of households below the poverty line (i.e., the poverty rate), an index of inequality or social disorganization, which also captures the relative cost of crime; a daily interpolation of the location's unemployment rate (averaged over the months of the year); a daily interpolation of the state's average annual retail wage rate; the running total extent (acres) of lagged wildfire in the previous zero to two and three to six years; the running total permitted prescribed burning extent (acres) in the previous zero to one and one to two years; a daily observation of a drought measure, the Keetch-Byram Drought Index (KBDI); dummy variables that index weekend days and holidays (representing more time available for firesetting, possibly measuring lower opportunity costs of time); and dummy variables that index months, accounting for other sources of intra-annual seasonality. Further, the specification includes a time index that controls for an unknown set of slowly changing factors, such as population, the amount of wildland, and law enforcement technology. Finally, autoregressivity in wildland arson is captured by lagged arson wildfire ignitions. ${ }^{7}$ The order of autoregression varies by location, depending on the availability of sufficiently long-lasting arson clusters to permit parameter identification. ${ }^{8}$

\footnotetext{
${ }^{6}$ The annual arson ignition model is how we seek to correct for this inferential limitation.

${ }^{7}$ We included total population in an initial empirical specification, but it was omitted due to nonconvergence. Hence, the primary effect of population (its absolute level) is contained in the intercept of our daily models. Population is included, however, in the annual model.

${ }^{8}$ GAUSS 5.0 with the Maximum Likelihood 5.0 Application Module (Aptech Systems, Inc.) was used to estimate the $\operatorname{PAR}(p)$, model. Parts of the programming code (designed for GAUSS 3.0) were provided by Brandt and Williams (2002), although we updated this code to make it compatible with the later version of GAUSS and our particular modeling framework. NLOGIT 3.0 (Greene) was used to estimate the fixed effects Poisson model.
} 
A pooled version of the $\operatorname{PAR}(p)$ individuallocation model is also estimated for the five locations. The pooled version is estimated to test inferences with a larger dataset and to quantify more precisely the average amount of autoregressivity present. One way to estimate a pooled version would be to incorporate cross-sectional dummy variables, a $\operatorname{PAR}(p)$ equivalent to a dummy variable or a fixed effects panel time-series model. However, no statistical methods for the panel $\operatorname{PAR}(p)$ model are available. Here, we assume that parameters of individual-location versions of equation (5) differ across cross-sections only by a factor proportional to the population of the location. Multiplying the nonautoregressive terms on the right-hand side of (5) by population effectively controls for this proportional difference. Because of these interactions, the right-hand side of (5) also includes population on day $t$. The intercept is still required for statistical consistency. The time period of inference varies by location but roughly covers January 8, 1994 to December 31, 2001.

\section{Annual Arson Ignitions}

The annual model of arson ignitions is a fixedeffects panel Poisson process. In each year, the arson ignition count is the sum of the arson fire outcomes resulting from $I$ daily decisions on firesetting across all days of the year. For cross-sectional units $j=1, \ldots, J$ and years $\tau=$ $1, \ldots, T, y_{j, \tau}$, the density of this annual count is described as (Greene)

$$
\begin{gathered}
f\left(y_{j, \tau} \mid \mathbf{x}_{j, 1}, \mathbf{x}_{j, 2}, \ldots, \mathbf{x}_{j, \mathrm{~T}}\right) \\
=g\left(y_{j, \tau}, \mathbf{x}_{j, \tau}^{\prime} \boldsymbol{\beta}+\alpha_{j}\right)
\end{gathered}
$$

where the $\alpha_{j}$ 's are cross-sectionally related fixed intercepts. The fixed-effects Poisson count model $^{9}$ has an expected count,

$$
\mathrm{E}\left(y_{j, \tau} \mid \mathbf{X}_{\tau}\right)=\lambda_{j, \tau}=\exp \left(\mathbf{x}_{j, \tau}^{\prime} \boldsymbol{\beta}+\alpha_{j}\right)
$$

The likelihood equation to maximize is

$$
\begin{aligned}
\log L= & \sum_{j=1}^{J} \sum_{\tau=1}^{\mathrm{T}}-\exp \left(\alpha_{j}\right) \exp \left(\mathbf{x}_{j, \tau}^{\prime} \boldsymbol{\beta}\right) \\
& +y_{j, \tau}\left(\mathbf{x}_{j, \tau}^{\prime} \boldsymbol{\beta}+\alpha_{j}\right)-\log y_{j, \tau} !
\end{aligned}
$$

\footnotetext{
${ }^{9}$ We confine our discussion to the Poisson model. In empirical estimates for this analysis, the standard alternative model, the negative binomial, which accounts for overdispersion, did not converge in estimation.
}

where

$$
-\exp \left(\alpha_{j}\right)=\frac{\sum_{\tau=1}^{\mathrm{T}} y_{j, \tau}}{\sum_{\tau=1}^{\mathrm{T}} \exp \left(\mathbf{x}_{j, \tau}^{\prime} \boldsymbol{\beta}\right)} .
$$

As in the case of the daily model of wildland arson, the annual specification includes variables related to law enforcement, economic conditions, fuels and fuels management, and weather. Variables included are: current year police officers per capita, the poverty rate, the average annual unemployment rate, the statelevel average annual retail wage rate, twelve separate years of lags of wildfire area burned (acres), the current and previous year's permitted hazard reduction prescribed burning (acres), and the total pulpwood harvest volume in each of the three previous years in the county (thousands of cubic feet). Average weather statewide is quantified by the year's average Niño-3 sea surface temperature (SST) anomaly $\left({ }^{\circ} \mathrm{C}\right)$, which is a measure of the $\mathrm{El}$ Niño-Southern Oscillation, and a dummy variable that accounts for the unusual El Niño of 1997-8 (see Prestemon et al.). To control for other trends related to population and aggregate urban growth (which also consumes fuels), we include county population and a state-level time trend. Finally, county fixed effects measure cross-sectionally varying factors that did not change significantly over the period of inference, 1995-2001, such as ecological variables.

\section{Data}

Wildfire and prescribed fire permit data were obtained directly from the Florida Division of Forestry. Arson wildfires were those deemed by the Division as likely arson, but uncertainty means that an unknown number of fires were misclassified. ${ }^{10}$ Local population estimates were from the Florida Bureau of Economic and Business Research, while annual poverty data were from the United States Department of Commerce, Census Bureau. The Florida Department of Law Enforcement (2002) provided data on the mid-year count of full-time equivalent police officers in each county. The retail wage rate in our models was the state-level average for the year, from the United States Department of Labor (2004).

\footnotetext{
${ }^{10}$ Any wildfire of suspicious origin is investigated, and correct classification of its cause is highly likely, according to Division personnel. Nevertheless, classification errors would result in an unknown degree of statistical inconsistency in parameter estimates.
} 
Table 1. Summary Statistics for Five (Two- and Single-County) Locations in Florida, for the Daily Model

\begin{tabular}{|c|c|c|c|c|c|}
\hline \multirow[b]{2}{*}{ Variables } & \multicolumn{5}{|c|}{ County Aggregate } \\
\hline & $\begin{array}{c}\text { Dixie + } \\
\text { Taylor }\end{array}$ & $\begin{array}{l}\text { Duval + } \\
\text { St. Johns }\end{array}$ & $\begin{array}{c}\text { Sarasota }+ \\
\text { Charlotte }\end{array}$ & $\begin{array}{l}\text { Santa } \\
\text { Rosa }\end{array}$ & $\begin{array}{c}\text { Volusia }+ \\
\text { Flagler }\end{array}$ \\
\hline \multicolumn{6}{|c|}{ Arson ignitions/day } \\
\hline Mean & 0.18 & 0.20 & 0.25 & 0.24 & 0.20 \\
\hline Maximum & 18 & 8 & 7 & 17 & 5 \\
\hline Minimum & 0 & 0 & 0 & 0 & 0 \\
\hline SD & 0.89 & 0.58 & 0.77 & 0.88 & 0.57 \\
\hline \multicolumn{6}{|l|}{ Police officers } \\
\hline Mean & 48 & 1,738 & 405 & 654 & 1,113 \\
\hline Maximum & 50 & 1,859 & 445 & 730 & 1,217 \\
\hline Minimum & 45 & 1,564 & 355 & 568 & 1,005 \\
\hline $\mathrm{SD}$ & 1 & 84 & 22 & 46 & 60 \\
\hline \multicolumn{6}{|c|}{ Poverty rate ( $\%$ of population) } \\
\hline Mean & 20.09 & 15.04 & 8.82 & 11.25 & 13.78 \\
\hline Maximum & 23.06 & 16.73 & 9.78 & 12.50 & 14.87 \\
\hline Minimum & 15.52 & 14.02 & 7.83 & 4.89 & 12.02 \\
\hline SD & 2.50 & 0.82 & 0.62 & 1.37 & 1.02 \\
\hline \multicolumn{6}{|c|}{ Unemployment rate (\% of population) } \\
\hline Mean & $7.94^{1}$ & 3.50 & 2.87 & 3.85 & 3.68 \\
\hline Maximum & 11.75 & 4.97 & 4.33 & 5.70 & 5.24 \\
\hline Minimum & 5.26 & 2.53 & 1.85 & 2.81 & 2.64 \\
\hline SD & 1.40 & 0.46 & 0.54 & 0.50 & 0.62 \\
\hline \multicolumn{6}{|c|}{ Real wage rate (2001 \$/yr) } \\
\hline Mean & 16,564 & 16,745 & 16,719 & 16,765 & 16,723 \\
\hline Maximum & 17,468 & 17,669 & 17,631 & 17,707 & 17,631 \\
\hline Minimum & 16,146 & 16,146 & 16,146 & 16,146 & 16,146 \\
\hline SD & 375 & 480 & 464 & 496 & 464 \\
\hline \multicolumn{6}{|c|}{ Wildfire (ac/yr) } \\
\hline Mean & 4,126 & 4,631 & 5,478 & 2,663 & 42,159 \\
\hline Maximum & 21,605 & 22,661 & 12,836 & 5,082 & 263,026 \\
\hline Minimum & 70 & 411 & 843 & 644 & 754 \\
\hline SD & 7,559 & 6,836 & 3,266 & 1,438 & 91,688 \\
\hline \multicolumn{6}{|c|}{ Hazardous burn permits (ac/yr) } \\
\hline Mean & 3,056 & 1,348 & 5,034 & 14,236 & 4,203 \\
\hline Maximum & 9,055 & 4,676 & 20,316 & 38,061 & 14,719 \\
\hline Minimum & 24 & 0 & 0 & 571 & 51 \\
\hline $\mathrm{SD}$ & 2,366 & 1,272 & 6,125 & 8,986 & 3,968 \\
\hline \multicolumn{6}{|c|}{ Population (thousands) } \\
\hline Mean & 18.3 & 785.7 & 338.4 & 109.9 & 436.0 \\
\hline Maximum & 18.9 & 822.3 & 356.7 & 122.7 & 461.6 \\
\hline Minimum & 17.6 & 745.3 & 322.3 & 96.5 & 412.2 \\
\hline SD & 0.4 & 23.2 & 10.0 & 8.4 & 15.1 \\
\hline \multicolumn{6}{|c|}{ Keetch-Byram drought index } \\
\hline Mean & 314 & 295 & 431 & 222 & 312 \\
\hline Maximum & 721 & 733 & 783 & 681 & 694 \\
\hline Minimum & 0 & 1 & 4 & 0 & 1 \\
\hline $\mathrm{SD}$ & 217 & 166 & 195 & 183 & 181 \\
\hline
\end{tabular}

County unemployment data were from the United States Department of Labor (2002). The current day's KBDI was constructed using an algorithm (Keetch and Byram) from representative weather station data in the study area, which were collected by the National Climatic Data Center and provided by EarthInfo, Inc.
Table 1 presents summary statistics for nonseasonal, nontrend variables that we use in the $\operatorname{PAR}(p)$ modeling. Average daily arson ignitions are similar across the five locations during the sample period, although the maxima observed in each varied more-up to 18 in one case in the Dixie-Taylor county aggregate. The full-time equivalent police 
officers per county vary from under 50 to over 1,700 . Poverty rates in the Dixie-Taylor aggregate are double those observed in the Sarasota-Charlotte aggregate, and those two locations represent the highest and lowest rates of unemployment. The state-level wage rate does not vary across locations, of course, so differences in summary statistics for each location are caused by differences in sample periods, which are constrained by the availability of weather data. Wildfire area burned varies by nearly two orders magnitude across locations (large fires in Volusia and Flagler counties in 1998 distort that location's average and standard deviation upward), but prescribed fire rates are less variable. Population varies widely-Dixie and Taylor are mainly rural counties, while most of the rest are more urbanized, with higher pressures on the wildland resource in the latter group. As is clear from the data on the KBDI, weather-related fire danger is highly variable over the sample periods for all locations, with values ranging from the index minimum of 0 (soil saturation) to near its maximum of 800 (maximum soil moisture deficiency or maximum drought conditions) (Keetch and Byram).

Additional data not shown in table 1 but used in the annual arson fixed-effects modeling include pulpwood harvest data, obtained by special request from the Southern Research Station of the United States Department of Agriculture, Forest Service, and the Niño-3 SST anomaly, obtained from the National Oceanic and Atmospheric Administration. Summary statistics by county aggregate on these and the other variables included in the county-level annual fixed-effects model are available from the authors upon request. We note here that the data summarized in table 1 for the daily models approximate the statewide variability of most modeled variables in the annual models.

\section{Results}

\section{Daily PAR(p) Model Results}

Daily time-series arson ignition models are broadly significant, and the included variables explain a large share of the variation in ignitions in each location (table 2) and in the pooled data model (table 3 ). Although $\operatorname{PAR}(p)$ model estimates were attempted with up to twelve autoregressive terms for all locations, parameter identification restrictions allowed only smaller versions to be estimated. The most commonly statistically significant determinants of arson ignitions are police officers per capita (negatively related), a dummy variable for Saturday (with the expected positive effect), the high-fire season months of the year (positively), and the autoregressive terms. The poverty rate, expected to have a positive influence, is statistically significant in two cases-in the Volusia-Flagler estimate and in the pooled estimate, in both cases with the expected sign. Unemployment and retail wages are related to arson in directions not found in other research; they are usually statistically insignificant, but wages are unexpectedly and significantly positively related to arson in the pooled model. The number of statistically significant autoregressive terms varies between six and eleven, the most in the pooled model. Tests of model restrictions that the autoregressive parameters are jointly zero are rejected at less than the $1 \%$ significance level in all daily models.

Significance tests show that arson wildfire ignitions also vary with weather and fuels. Higher Keetch-Byram drought indices are linked to higher arson counts, other variables held constant. The lagged wildfire and prescribed fire variables, both being inversely related to fuel loads, are only occasionally statistically significant. In those few cases, the measured effects of these variables are negative, as expected.

To assess the net effect of explicitly accounting for autocorrelation in daily arson ignitions, we compare average elasticities produced by the individual-location and pooled $\operatorname{PAR}(p)$ models with counterpart nonautoregressive Poisson alternative specifications (table 4). When the parameter estimates of the $\operatorname{PAR}(p)$ model are statistically significant, usually so too are their nonautoregressive counterparts. However, significance levels differ between the $\operatorname{PAR}(p)$ and the Poisson in several instances. For example, in the pooled specification, the Poisson model indicates that police are positively related to arson rates, while the $\operatorname{PAR}(p)$ model shows no significant influence (and a negative effect in two individual-location models). The Poisson model estimate provides evidence that wildland arson ignitions are significantly and negatively linked to lagged wildfire and prescribed burning, while the $\operatorname{PAR}(p)$ model indicates no effect. These conflicting results suggest a relationship between some observed variables and the underlying autoregressive pattern, which the $\operatorname{PAR}(p)$ model specifically handles but the static model does not. In general, the 
Table 2. Poisson Autoregressive Models of Maximum Order Estimable, Five Study Areas in Florida, Daily Counts of Wildland Arson Ignitions, 1994-2001

\begin{tabular}{|c|c|c|c|c|c|}
\hline \multirow[b]{2}{*}{ Variables } & \multicolumn{5}{|c|}{ Model Locations } \\
\hline & $\begin{array}{l}\text { Dixie- } \\
\text { Taylor }\end{array}$ & $\begin{array}{l}\text { Duval-St. } \\
\text { Johns }\end{array}$ & $\begin{array}{l}\text { Santa } \\
\text { Rosa }\end{array}$ & $\begin{array}{l}\text { Sarasota- } \\
\text { Charlotte }\end{array}$ & $\begin{array}{l}\text { Volusia- } \\
\text { Flagler }\end{array}$ \\
\hline Constant & $\begin{aligned} 52.69^{*} \\
(29.95)\end{aligned}$ & $\begin{array}{c}-28.82 \\
(85.24)\end{array}$ & $\begin{array}{c}-27.92^{* *} \\
(13.06)\end{array}$ & $\begin{array}{c}11.46 \\
(30.24)\end{array}$ & $\begin{array}{c}-59.32 \\
(43.04)\end{array}$ \\
\hline Police per capita & $\begin{array}{c}-1.30^{* *} \\
(0.58)\end{array}$ & $\begin{array}{c}0.39 \\
(2.82)\end{array}$ & $\begin{array}{c}0.15 \\
(0.18)\end{array}$ & $\begin{array}{l}-4.16^{* * *} \\
(1.20)\end{array}$ & $\begin{array}{c}0.17 \\
(1.18)\end{array}$ \\
\hline Poverty rate & $\begin{array}{l}-0.16 \\
(0.62)\end{array}$ & $\begin{array}{r}-0.02 \\
(0.55)\end{array}$ & $\begin{array}{c}0.14 \\
(0.20)\end{array}$ & $\begin{aligned} 2.96^{*} \\
(1.65)\end{aligned}$ & $\begin{array}{l}0.95 \\
(0.77)\end{array}$ \\
\hline Unemployment rate & $\begin{array}{l}4.55 \\
(3.67)\end{array}$ & $\begin{array}{c}9.34 \\
(11.24)\end{array}$ & $\begin{array}{l}-3.57 \\
(2.48)\end{array}$ & $\begin{array}{l}-7.15^{* * *} \\
(1.70)\end{array}$ & $\begin{array}{l}3.60 \\
(5.74)\end{array}$ \\
\hline Real retail wage & $\begin{array}{c}-1.65 \\
(1.22)\end{array}$ & $\begin{array}{c}0.96 \\
(1.19)\end{array}$ & $\begin{array}{l}1.12 \\
(0.72)\end{array}$ & $\begin{array}{c}0.39 \\
(0.74)\end{array}$ & $\begin{array}{l}2.21^{*} \\
(1.19)\end{array}$ \\
\hline Wildfire years $\tau$ to $\tau-2$ & $\begin{array}{c}-0.45 \\
(0.41)\end{array}$ & $\begin{array}{l}0.08 \\
(0.63)\end{array}$ & $\begin{array}{l}-3.52^{* * *} \\
(1.27)\end{array}$ & $\begin{array}{c}-0.87 \\
(0.53)\end{array}$ & $\begin{array}{l}-0.01 \\
(0.03)\end{array}$ \\
\hline Wildfire years $\tau-3$ to $\tau-5$ & $\begin{array}{c}-0.75 \\
(1.51)\end{array}$ & $\begin{array}{l}-0.50 \\
(0.59)\end{array}$ & $\begin{array}{l}-1.29 \\
(1.44)\end{array}$ & $\begin{array}{c}0.18 \\
(0.24)\end{array}$ & $\begin{array}{l}-0.01 \\
(0.05)\end{array}$ \\
\hline Prescribed fire year $\tau$ & $\begin{array}{l}3.49^{* *} \\
(1.61)\end{array}$ & $\begin{array}{l}2.07 \\
(2.18)\end{array}$ & $\begin{array}{c}0.31 \\
(0.20)\end{array}$ & $\begin{array}{c}-0.11 \\
(0.18)\end{array}$ & $\begin{array}{l}1.54^{*} \\
(0.94)\end{array}$ \\
\hline Prescribed fire year $\tau-1$ & $\begin{array}{l}-0.25 \\
(1.01)\end{array}$ & $\begin{array}{l}1.24 \\
(2.14)\end{array}$ & $\begin{array}{l}-0.07 \\
(0.16)\end{array}$ & $\begin{array}{r}-0.22 \\
(0.23)\end{array}$ & $\begin{array}{l}0.04 \\
(0.66)\end{array}$ \\
\hline KBDI & $\begin{array}{l}0.39^{* * *} \\
(0.10)\end{array}$ & $\begin{array}{l}0.32^{* * *} \\
(0.09)\end{array}$ & $\begin{array}{l}0.26^{* * *} \\
(0.08)\end{array}$ & $\begin{array}{l}0.32^{* * * *} \\
(0.06)\end{array}$ & $\begin{array}{l}0.30^{* * *} \\
(0.09)\end{array}$ \\
\hline Saturday & $\begin{array}{l}1.18^{* * *} \\
(0.28)\end{array}$ & $\begin{array}{l}0.61^{* *} \\
(0.29)\end{array}$ & $\begin{array}{c}0.30 \\
(0.28)\end{array}$ & $\begin{array}{c}0.060 \\
(0.078)\end{array}$ & $\begin{array}{l}0.70^{* *} \\
(0.31)\end{array}$ \\
\hline Sunday & $\begin{array}{l}0.46^{*} \\
(0.27)\end{array}$ & $\begin{array}{c}0.11 \\
(0.38)\end{array}$ & $\begin{array}{l}-0.02 \\
(0.25)\end{array}$ & $\begin{array}{c}0.047 \\
(0.081)\end{array}$ & $\begin{array}{l}0.27 \\
(0.32)\end{array}$ \\
\hline Holiday & $\begin{array}{l}0.36 \\
(0.54)\end{array}$ & $\begin{array}{l}1.90^{* * * *} \\
(0.31)\end{array}$ & $\begin{array}{l}-0.67 \\
(0.57)\end{array}$ & $\begin{array}{l}0.10 \\
(0.16)\end{array}$ & $\begin{array}{l}0.31 \\
(0.48)\end{array}$ \\
\hline January & $\begin{array}{l}0.33 \\
(0.48)\end{array}$ & $\begin{array}{c}0.48 \\
(0.52)\end{array}$ & $\begin{array}{l}2.06^{* * *} \\
(0.52)\end{array}$ & $\begin{array}{c}0.50 \\
(0.34)\end{array}$ & $\begin{array}{l}0.47 \\
(0.49)\end{array}$ \\
\hline February & $\begin{array}{l}1.72^{* * *} \\
(0.52)\end{array}$ & $\begin{array}{l}1.40^{* * *} \\
(0.49)\end{array}$ & $\begin{array}{l}2.35^{* * *} \\
(0.49)\end{array}$ & $\begin{array}{c}0.46 \\
(0.34)\end{array}$ & $\begin{array}{l}1.28^{* * *} \\
(0.47)\end{array}$ \\
\hline March & $\begin{array}{l}1.50^{* * *} \\
(0.61)\end{array}$ & $\begin{array}{l}1.17^{* *} \\
(0.53)\end{array}$ & $\begin{array}{l}1.40^{* *} \\
(0.55)\end{array}$ & $\begin{array}{l}0.61^{*} \\
(0.34)\end{array}$ & $\begin{array}{l}0.44 \\
(0.56)\end{array}$ \\
\hline April & $\begin{array}{c}0.33 \\
(0.64)\end{array}$ & $\begin{array}{l}1.51^{* * *} \\
(0.50)\end{array}$ & $\begin{array}{l}1.31^{* *} \\
(0.53)\end{array}$ & $\begin{array}{l}0.81^{* *} \\
(0.34)\end{array}$ & $\begin{array}{l}0.78 \\
(0.52)\end{array}$ \\
\hline May & $\begin{array}{c}0.24 \\
(0.60)\end{array}$ & $\begin{array}{c}0.43 \\
(0.55)\end{array}$ & $\begin{array}{c}0.79 \\
(0.56)\end{array}$ & $\begin{array}{l}0.76^{* *} \\
(0.36)\end{array}$ & $\begin{array}{c}0.27 \\
(0.55)\end{array}$ \\
\hline June & $\begin{array}{l}0.50 \\
(0.78)\end{array}$ & $\begin{array}{c}-0.43 \\
(0.81)\end{array}$ & $\begin{array}{c}0.03 \\
(0.65)\end{array}$ & $\begin{array}{c}-0.11 \\
(0.54)\end{array}$ & $\begin{array}{l}-0.60 \\
(0.69)\end{array}$ \\
\hline July & $\begin{array}{c}-1.04 \\
(0.82)\end{array}$ & $\begin{array}{l}-0.10 \\
(0.60)\end{array}$ & $\begin{array}{l}-0.45 \\
(0.61)\end{array}$ & $\begin{array}{c}-0.73 \\
(0.57)\end{array}$ & $\begin{array}{c}0.35 \\
(0.61)\end{array}$ \\
\hline August & $\begin{array}{c}-0.33 \\
(0.87)\end{array}$ & $\begin{array}{c}0.06 \\
(0.60)\end{array}$ & $\begin{array}{c}-0.70 \\
(0.62)\end{array}$ & $\begin{array}{r}-1.11^{*} \\
(0.67)\end{array}$ & $\begin{array}{c}-0.75 \\
(0.68)\end{array}$ \\
\hline September & $\begin{array}{c}-0.90 \\
(0.94)\end{array}$ & $\begin{array}{c}-1.26 \\
(1.07)\end{array}$ & $\begin{array}{c}-0.46 \\
(0.61)\end{array}$ & $\begin{array}{c}0.21 \\
(0.48)\end{array}$ & $\begin{array}{c}-0.38 \\
(0.64)\end{array}$ \\
\hline October & $\begin{array}{c}-0.18 \\
(0.75)\end{array}$ & $\begin{array}{c}0.48 \\
(0.55)\end{array}$ & $\begin{array}{c}0.35 \\
(0.57)\end{array}$ & $\begin{array}{c}0.36 \\
(0.47)\end{array}$ & $\begin{array}{c}-1.28 \\
(0.82)\end{array}$ \\
\hline November & $\begin{array}{c}-0.87 \\
(0.72)\end{array}$ & $\begin{array}{c}-1.00 \\
(0.90)\end{array}$ & $\begin{array}{c}0.32 \\
(0.57)\end{array}$ & $\begin{array}{c}-0.40 \\
(0.49)\end{array}$ & $\begin{array}{c}0.35 \\
(0.55)\end{array}$ \\
\hline Time & $\begin{array}{c}0.25 \\
(0.28)\end{array}$ & $\begin{array}{c}-0.12 \\
(0.30)\end{array}$ & $\begin{array}{c}0.04 \\
(0.05)\end{array}$ & $\begin{array}{l}0.39^{* *} \\
(0.18)\end{array}$ & $\begin{array}{c}0.05 \\
(0.18)\end{array}$ \\
\hline Arson ignitions day $t-1$ & $\begin{array}{c}0.009 \\
(0.038)\end{array}$ & $\begin{array}{l}0.20^{* * *} \\
(0.04)\end{array}$ & $\begin{array}{l}0.29^{* * *} \\
(0.05)\end{array}$ & $\begin{array}{l}0.14^{* * *} \\
(0.04)\end{array}$ & $\begin{array}{l}0.22^{* * *} \\
(0.05)\end{array}$ \\
\hline Arson ignitions day $t-2$ & $\begin{array}{c}0.036 \\
(0.035)\end{array}$ & $\begin{array}{l}0.16^{* * *} \\
(0.04)\end{array}$ & $\begin{array}{c}0.038 \\
(0.035)\end{array}$ & $\begin{array}{l}0.10^{* * * *} \\
(0.04)\end{array}$ & $\begin{array}{l}0.091^{* *} \\
(0.043)\end{array}$ \\
\hline
\end{tabular}


Table 2. Continued

\begin{tabular}{|c|c|c|c|c|c|}
\hline \multirow[b]{2}{*}{ Variables } & \multicolumn{5}{|c|}{ Model Locations } \\
\hline & $\begin{array}{l}\text { Dixie- } \\
\text { Taylor }\end{array}$ & $\begin{array}{c}\text { Duval-St. } \\
\text { Johns }\end{array}$ & $\begin{array}{l}\text { Santa } \\
\text { Rosa }\end{array}$ & $\begin{array}{l}\text { Sarasota- } \\
\text { Charlotte }\end{array}$ & $\begin{array}{l}\text { Volusia- } \\
\text { Flagler }\end{array}$ \\
\hline Arson ignitions day $t-3$ & $\begin{array}{l}0.17^{* * *} \\
(0.05)\end{array}$ & $\begin{array}{r}0.055^{*} \\
(0.033)\end{array}$ & $\begin{array}{r}0.060^{*} \\
(0.034)\end{array}$ & $\begin{array}{r}0.055^{*} \\
(0.032)\end{array}$ & $\begin{array}{r}0.067^{*} \\
(0.040)\end{array}$ \\
\hline Arson ignitions day $t-4$ & $\begin{array}{l}0.088^{* *} \\
(0.041)\end{array}$ & $\begin{array}{c}0.042 \\
(0.030)\end{array}$ & $\begin{array}{l}0.13^{* * *} \\
(0.04)\end{array}$ & $\begin{aligned} 0.060^{*} \\
(0.033)\end{aligned}$ & $\begin{array}{l}0.12^{* * *} \\
(0.04)\end{array}$ \\
\hline Arson ignitions day $t-5$ & $\begin{array}{c}0.027 \\
(0.045)\end{array}$ & $\begin{array}{l}0.013 \\
(0.029)\end{array}$ & $\begin{array}{c}0.00 \\
(0.03)\end{array}$ & $\begin{array}{c}0.051 \\
(0.034)\end{array}$ & $\begin{array}{c}0.024 \\
(0.036)\end{array}$ \\
\hline Arson ignitions day $t-6$ & $\begin{array}{r}0.076^{*} \\
(0.046)\end{array}$ & $\begin{array}{l}0.14^{* * *} \\
(0.04)\end{array}$ & $\begin{array}{c}0.043 \\
(0.030)\end{array}$ & $\begin{array}{c}0.017 \\
(0.034)\end{array}$ & $\begin{array}{l}0.11^{* * *} \\
(0.04)\end{array}$ \\
\hline Arson ignitions day $t-7$ & & $\begin{array}{l}0.087 * * * \\
(0.033)\end{array}$ & $\begin{array}{l}0.032 \\
(0.034)\end{array}$ & $\begin{array}{l}0.066^{* *} \\
(0.033)\end{array}$ & $\begin{array}{l}0.10^{* *} \\
(0.04)\end{array}$ \\
\hline Arson ignitions day $t-8$ & & $\begin{array}{l}0.060^{*} \\
(0.035)\end{array}$ & & $\begin{array}{l}0.012 \\
(0.03)\end{array}$ & $\begin{array}{l}0.043 \\
(0.028)\end{array}$ \\
\hline Arson ignitions day $t-9$ & & $\begin{array}{l}0.030 \\
(0.025)\end{array}$ & & & $\begin{array}{c}0.033 \\
(0.038)\end{array}$ \\
\hline Arson ignitions day $t-10$ & & $\begin{array}{l}0.089^{* * *} \\
(0.03)\end{array}$ & & & $\begin{array}{l}0.055 \\
(0.034)\end{array}$ \\
\hline Arson ignitions day $t-11$ & & & & & $\begin{array}{l}0.057 \\
(0.035)\end{array}$ \\
\hline Observations & 1,915 & 2,476 & 2,552 & 2,433 & 2,413 \\
\hline $\operatorname{LL} \operatorname{PAR}(p)$ model & -723.75 & $-1,167.16$ & $-1,299.74$ & $-1,232.42$ & $-1,143.24$ \\
\hline $\operatorname{LL} \operatorname{PAR}(p)$, all $\rho_{i}=0$ & -741.18 & $-1,219.88$ & $-1,347.48$ & $-1,258.41$ & $-1,169.53$ \\
\hline LL null model & $-1,179.93$ & $-1,406.35$ & $-1,825.50$ & $-1,711.01$ & $-1,370.41$ \\
\hline $\begin{array}{l}\text { Wald stat, } \operatorname{PAR}(p) \\
\quad \text { vs. all } \rho_{i}=0\end{array}$ & $34.87^{* * *}$ & $105.45^{* * *}$ & $95.49^{* * *}$ & $51.96^{* * *}$ & $52.58^{* * *}$ \\
\hline $\begin{array}{l}\text { Wald stat } \operatorname{PAR}(p) \\
\text { vs. null model }\end{array}$ & $912.37^{* * *}$ & $478.39^{* * *}$ & $1,051.52^{* * *}$ & $957.18^{* * *}$ & $454.34^{* * *}$ \\
\hline
\end{tabular}

Note: Standard errors of the estimates, in parentheses, computed as the inverse of the information matrix.

${ }^{* * *}$ Indicates that Wald tests were rejected or that hypotheses tests reject the null that parameters are zero at $1 \%$ significance, ${ }^{* *}$ at $5 \%$, and ${ }^{*}$ at $10 \%$.

magnitudes of the two sets of elasticities for $\operatorname{PAR}(p)$ and Poisson estimates are similar, so our estimates demonstrate, in this empirical case, no tendency of the Poisson model parameter estimates to be attenuated compared to those produced by the $\operatorname{PAR}(p)$ model.

\section{Annual Fixed-Effects Poisson Model Results}

The fixed-effects panel Poisson count model estimate broadly supports hypotheses relating the crime of wildland arson to socioeconomic, ecological, and managerial factors (table 5). Consistent with theory and our results for two locations in the daily count models, police officers per capita are negatively and statistically significantly related to annual wildland arson counts. The poverty rate is positively related to wildland arson, as expected. Parallel to the most recent theoretical developments and empirical findings for major crimes, wage rates are negatively related to wildland arson ignitions. The higher wage rates occurring in the late 1990s might offer a partial explanation for lower arson rates observed in our data, just as they were found by others to partially explain lower crime rates generally. Unemployment, another measure of the opportunity costs of crime, is not significantly related to arson ignitions, consistent with some results on major crimes found by Gould, Weinberg, and Mustard. The coefficients on the time trend and population are positive and negative, respectively, which is somewhat counterintuitive. Population's negative effect might be due to the loss of wildland areas, which usually results from development, where such crimes can occur-a loss in firesetting locations that is greater than the added new arsonists that an increase in population could bring. We cannot explain the positive trend in wildland arson, once all other included variables are accounted for.

Consistent with previous wildfire risk modeling for Florida (Prestemon et al.), arson risk in the current year is related to fuels, fuels management, and weather. Arson counts are negatively related to previous years' wildfire extent, 
Table 3. Poisson Autoregressive (Pooled) Model, Daily Wildland Arson Ignition Counts in Five Locations in Florida, 1994-2001, as a Function of Population-Interacted Variables

\begin{tabular}{|c|c|c|c|}
\hline Variables & & Variables & \\
\hline Constant & $\begin{array}{c}0.09 \\
(0.17)\end{array}$ & August & $\begin{array}{r}-9.38 \\
(6.83)\end{array}$ \\
\hline Police per capita ${ }_{t}$ & $\begin{array}{c}-0.027 \\
(0.034)\end{array}$ & September & $\begin{array}{r}-15.11^{*} \\
(8.86)\end{array}$ \\
\hline Poverty rate $_{t}$ & $\begin{array}{l}2.90^{* * * *} \\
(0.94)\end{array}$ & October & $\begin{array}{c}-0.94 \\
(6.44)\end{array}$ \\
\hline 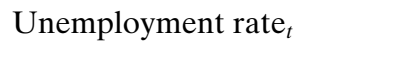 & $\begin{array}{l}3.30 \\
(2.63)\end{array}$ & November & $\begin{array}{r}-6.59 \\
(6.61)\end{array}$ \\
\hline Real retail wage t $_{t}$ & $\begin{array}{l}30.29^{* * *} \\
(5.67)\end{array}$ & Time $_{t}$ & $\begin{array}{l}-0.55^{* * *} \\
(0.09)\end{array}$ \\
\hline Wildfire years $\tau \tau \mathrm{o} \tau-2$ & $\begin{array}{c}0.024 \\
(0.017)\end{array}$ & Population $_{t}$ & $\begin{array}{l}-0.25^{* * *} \\
(0.04)\end{array}$ \\
\hline Wildfire years $\tau-3 \tau \mathrm{o} \tau-5$ & $\begin{array}{c}0.027 \\
(0.073)\end{array}$ & Arson ignitions day $t-1$ & $\begin{array}{l}0.25^{* * *} \\
(0.02)\end{array}$ \\
\hline Prescribed fire year $\tau$ & $\begin{array}{c}-0.31 \\
(0.32)\end{array}$ & Arson ignitions day $t-2$ & $\begin{array}{l}0.11^{* * *} \\
(0.02)\end{array}$ \\
\hline Prescribed fire year $\tau-1$ & $\begin{array}{r}-0.30 \\
(0.34)\end{array}$ & Arson ignitions day $t-3$ & $\begin{array}{l}0.07^{* * *} \\
(0.02)\end{array}$ \\
\hline $\mathrm{KBDI}_{t}$ & $\begin{array}{l}5.43^{* * *} \\
(0.77)\end{array}$ & Arson ignitions day $t-4$ & $\begin{array}{l}0.10^{* * *} \\
(0.02)\end{array}$ \\
\hline Saturday & $\begin{array}{l}8.06^{* *} \\
(3.42)\end{array}$ & Arson ignitions day $t-5$ & $\begin{array}{r}0.026^{*} \\
(0.015)\end{array}$ \\
\hline Sunday & $\begin{array}{c}2.12 \\
(3.26)\end{array}$ & Arson ignitions day $t-6$ & $\begin{array}{l}0.080^{* * *} \\
(0.017)\end{array}$ \\
\hline Holiday & $\begin{array}{l}20.84^{* * *} \\
(4.35)\end{array}$ & Arson ignitions day $t-7$ & $\begin{array}{l}0.073^{* * *} \\
(0.017)\end{array}$ \\
\hline January & $\begin{array}{c}5.74 \\
(5.42)\end{array}$ & Arson ignitions day $t-8$ & $\begin{array}{l}0.027^{* *} \\
(0.013)\end{array}$ \\
\hline February & $\begin{array}{l}21.44^{* * *} \\
(4.87)\end{array}$ & Arson ignitions day $t-9$ & $\begin{array}{l}0.042^{* * *} \\
(0.014)\end{array}$ \\
\hline March & $\begin{array}{l}14.58^{* * *} \\
(5.24)\end{array}$ & Arson ignitions day $t-10$ & $\begin{array}{l}0.035^{* * *} \\
(0.014)\end{array}$ \\
\hline April & $\begin{array}{l}17.99^{* * *} \\
(4.95)\end{array}$ & Arson ignitions day $t-11$ & $\begin{array}{l}0.030^{* *} \\
(0.014)\end{array}$ \\
\hline May & $\begin{array}{c}8.47 \\
(5.41)\end{array}$ & $\begin{array}{l}\text { Observations } \\
\text { LL PAR }(p) \text { model }\end{array}$ & $\begin{array}{l}11,789 \\
-5,805.12\end{array}$ \\
\hline June & $\begin{array}{r}-9.39 \\
(7.64)\end{array}$ & $\begin{array}{l}\operatorname{LL} \operatorname{PAR}(p) \text {, all } \rho_{i}=0 \\
\operatorname{LL} \text { null model }\end{array}$ & $\begin{array}{l}-6,125.51 \\
-7,512.39\end{array}$ \\
\hline July & $\begin{array}{r}-6.08 \\
(6.29)\end{array}$ & $\begin{array}{l}\text { Wald stat, } \operatorname{PAR}(p) \text { vs. all } \rho_{i}=0 \\
\text { Wald stat } \operatorname{PAR}(p) \text { vs. null model }\end{array}$ & $\begin{array}{r}640.78^{* * *} \\
3,414.54^{* * *}\end{array}$ \\
\hline
\end{tabular}

Note: Standard errors of the estimates, in parentheses, computed as the inverse of the information matrix.

${ }^{* * *}$ Indicates that Wald tests were rejected or that hypotheses tests reject the null that parameters are zero at $1 \%$ significance, ${ }^{* *}$ at $5 \%$, and ${ }^{*}$ at $10 \%$.

with coefficients on six out of the first seven years' lagged wildfire area negative and significantly different from zero at the $1 \%$ significance level. The twelfth year lag is positive and significant, indicating a returning risk many years after local fires. Because previous wildfires index fuel reductions and hence higher costs or lower success rates of wildland arson, this result accords with our expectation. Hazard reducing prescribed fire, another measure of fuels, is negatively related to arson ignition counts, also supporting our hypotheses about arson ignition costs or changed ignition success rates. On the other hand, pulpwood harvesting activities, sometimes done to thin forests and reduce fuel loads, are positively linked to ignitions. This can be explained by recognizing that harvesting can temporarily increase downed woody debris left over from cutting (e.g., tree tops, limbs), which provide fuel for fire. Arsonists might view such areas of recent harvests as places where arson success could be higher, so they target them. Finally, the measure of average weather, the Niño-3 SST anomaly, is 


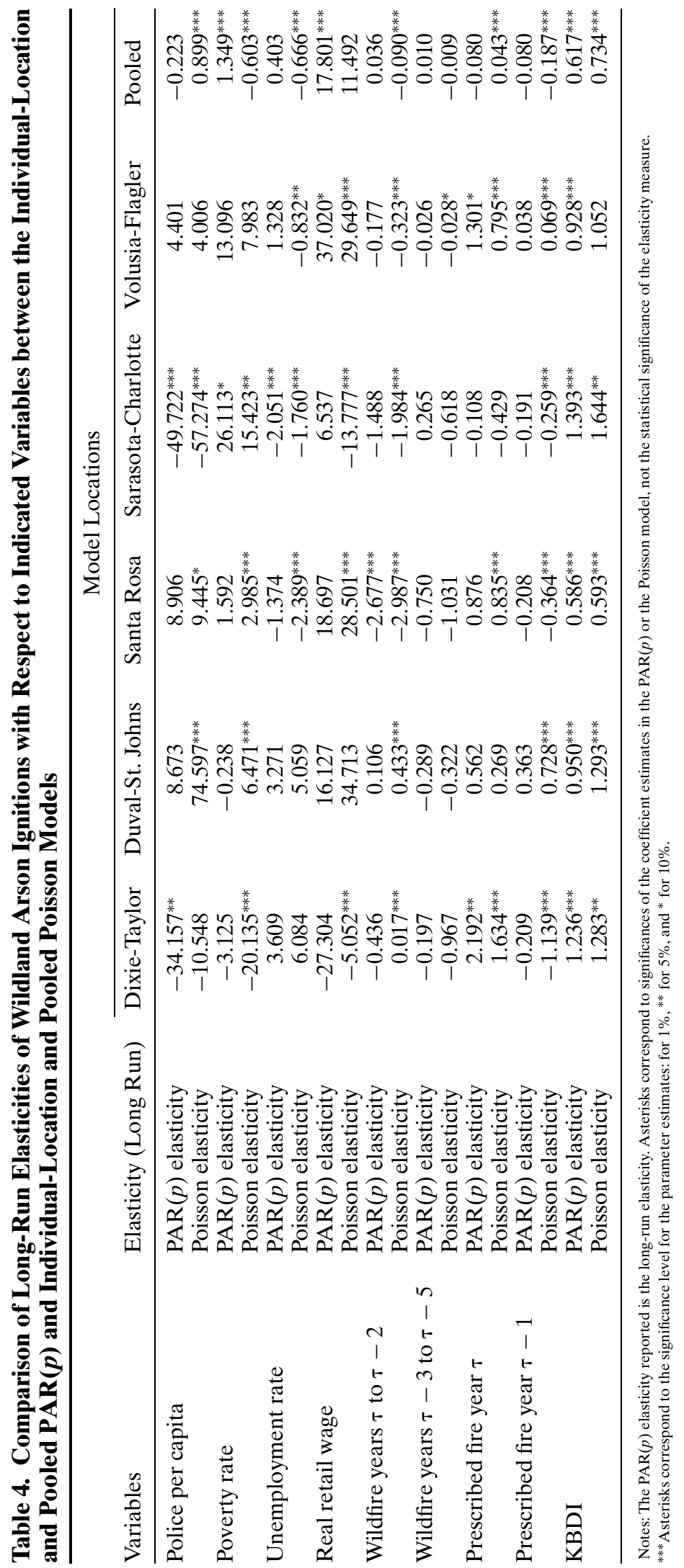


Table 5. Fixed-Effects Time-Series Poisson Model Estimate of Annual Wildland Arson Ignition Counts in Florida, 1995-2001

\begin{tabular}{|c|c|c|c|}
\hline Variables & Parameter Estimate & Variables & Parameter Estimate \\
\hline Police per capita ${ }_{\tau}$ & $\begin{array}{c}-0.61^{* *} \\
(0.20)\end{array}$ & Wildfire acres $_{\tau-11}$ & $\begin{array}{c}0.20 \\
(0.35)\end{array}$ \\
\hline Poverty rate $_{\tau}$ & $\begin{array}{l}1.75^{* *} \\
(0.85)\end{array}$ & Wildfire acres $_{\tau-12}$ & $\begin{array}{l}1.92^{* * *} \\
(0.36)\end{array}$ \\
\hline Unemployment rate ${ }_{\tau}$ & $\begin{array}{c}-1.39 \\
(2.86)\end{array}$ & Hazard prescribed fire acres $s_{\tau}$ & $\begin{array}{l}-0.84^{* * *} \\
(0.27)\end{array}$ \\
\hline Real retail wage $_{\tau}$ & $\begin{array}{l}-0.83^{* * *} \\
(0.26)\end{array}$ & Hazard prescribed fire acres ${ }_{\tau-1}$ & $\begin{array}{c}0.29 \\
(0.26)\end{array}$ \\
\hline${\text { Wildfire } \text { acres }_{\tau-1}}$ & $\begin{array}{l}-0.65^{* * *} \\
(0.12)\end{array}$ & Hazard prescribed fire acres $_{\tau-2}$ & $\begin{array}{c}0.47 \\
(0.34)\end{array}$ \\
\hline${\text { Wildfire } \text { acres }_{\tau-2}}$ & $\begin{array}{l}-0.37^{* * *} \\
(0.10)\end{array}$ & Pulpwood harvests $_{\tau-1}$ & $\begin{array}{l}3.20^{* * *} \\
(0.56)\end{array}$ \\
\hline${\text { Wildfire } \text { acres }_{\tau-3}}$ & $\begin{array}{l}-4.72^{* * *} \\
(0.76)\end{array}$ & Pulpwood harvests $_{\tau-2}$ & $\begin{array}{l}-1.10 \\
(0.70)\end{array}$ \\
\hline${\text { Wildfire } \text { acres }_{\tau-4}}$ & $\begin{array}{l}-2.46^{* * *} \\
(0.77)\end{array}$ & Pulpwood harvests $_{\tau-3}$ & $\begin{array}{c}0.29 \\
(0.65)\end{array}$ \\
\hline 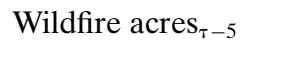 & $\begin{array}{l}-3.97^{* * *} \\
(0.67)\end{array}$ & Nino 3 SST anomaly ${ }_{\tau}$ & $\begin{array}{l}-0.18^{* * *} \\
(0.04)\end{array}$ \\
\hline${\text { Wildfire } \text { acres }_{\tau-6}}$ & $\begin{array}{c}0.21 \\
(0.44)\end{array}$ & 1998 dummy $_{\tau}$ & $\begin{array}{l}0.33^{* * *} \\
(0.09)\end{array}$ \\
\hline 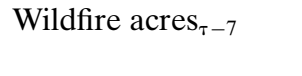 & $\begin{array}{l}-1.22^{* * *} \\
(0.42)\end{array}$ & Time $_{\tau}$ & $\begin{array}{l}0.28^{* * *} \\
(0.05)\end{array}$ \\
\hline${\text { Wildfire } \text { acres }_{\tau-8}}$ & $\begin{array}{c}0.50 \\
(0.36)\end{array}$ & Population $_{\tau}$ & $\begin{array}{r}-3.05^{*} \\
(1.66)\end{array}$ \\
\hline${\text { Wildfire } \text { acres }_{\tau-9}}$ & $\begin{array}{c}-0.04 \\
(0.36)\end{array}$ & $\begin{array}{l}\text { Observations } \\
\text { Log-likelihood, full model }\end{array}$ & $\begin{array}{c}402 \\
-1,129.86\end{array}$ \\
\hline 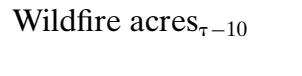 & $\begin{array}{c}0.57 \\
(0.35)\end{array}$ & $\begin{array}{l}\text { Log-likelihood, null model } \\
\text { Wald test, full vs. null }\end{array}$ & $\begin{aligned}-4,616.55 \\
6,973.39^{* * *}\end{aligned}$ \\
\hline
\end{tabular}

*** Indicates that Wald tests were rejected or that hypotheses tests reject the null that parameters are zero at $1 \%$ significance, ${ }^{* *}$ at $5 \%$, and ${ }^{*}$ at $10 \%$.

negatively related to arson ignitions, while the dummy variable accounting for extreme conditions related to the ENSO cycle of 1997-8 is positively related. Both of these effects were expected, based on previous wildfire modeling.

\section{Implications}

The time-series properties and general causes of wildland arson have not been adequately explored, and the research reported here, parallel to research into crime and human-caused wildfires, leads to four principal findings. First, wildland arson demonstrates temporal clustering, which supports hypotheses of either serial or copycat firesetting. As identified in all six cases analyzed, wildland arson demonstrates highly significant autocorrelation at the daily time scale, for periods lasting up to eleven days, just as has been shown for other types of crime. The apparent episodic pattern of arson implies that it has some short-run predictability, which should aid in developing tactical responses to arson outbreaks. Additionally, temporal clustering overlays weekly and intraannual patterns in firesetting that could be exploited by law enforcement and wildland fire managers to develop strategies that limit arson occurrence.

Combining our first finding with our evidence on law enforcement leads to our second finding, that law enforcement resource placement strategies could be effective. The statistical results reported here add to the support provided by published research in the wider field of criminology. Agencies could preposition law enforcement resources in locations where recent suspected wildland arson ignitions have occurred. They could also regularly increase arson enforcement on days and months of the year when ignitions are more common and during droughts. Specifically in Florida, this means raising enforcement levels on Saturdays and holidays and during the spring fire season. Also in Florida, some decisions can be made months in advance by 
monitoring forecasts of the El Niño-Southern Oscillation (e.g., Ji, Behringer, and Leetmaa).

Third, we find that locations with difficult economic conditions have higher rates of wildland arson, other variables held constant. The negative relationship with wages and positive relationship with poverty that we find in our annual model validates a contention that economic conditions matter and provides some evidence that arsonists behave consistent with an economic model of crime. Given this, another strategy by law enforcement would be to pay attention to wildland arson in times of economic downturns and in places with chronically low wages and high poverty.

Fourth, forest management activities are related to wildland arson. Sometimes, management exacerbates the risk of wildland arson, while other actions alleviate the risk. Although our statistical finding that timber harvesting activity is a positive risk factor is not proved to be causal, these results are consistent with other research (Prestemon et al.). In contrast, because fuel reductions caused by prescribed fire and previous wildfires are correlated with lower arson rates, it makes sense that managers could reduce arson rates by reducing available fuels. This finding is also consistent with an economic model of wildland arson crime, wherein lower fuels increase the cost of successful firesetting.

Our results highlight several research needs. First, daily models reported here are for high arson locations in Florida, so new research should explore whether the temporal clustering and seasonal patterns that we identify hold for other parts of the country. Second, a potentially fruitful area of new research is on how to augment the received optimal wildfire intervention models (e.g., Gorte and Gorte; Rideout and Omi) to include ignition counts, including those from arson, and their causes. Wildfire costs include a fixed amount, associated with ignitions, and a variable amount, associated with the size, severity, and duration of wildfires. The inclusion of counts would therefore capture the effects of demographic and socioeconomic changes over time that can affect aggregate wildfire risks. This is especially true in areas where the potential economic damages from wildfire are greatest (e.g., in the wildland-urban interface).

Third, our models have been estimated on a spatial scale that could be viewed as arbitrary, based on political boundaries rather than another objective metric. New research could evaluate the spatial scale most useful for de- tecting the effects of hypothesized influential factors, including economic conditions and law enforcement. For example, finer scale modeling could explicitly include the locations of recent arson ignitions to predict future ignitions nearby, information more useful for targeting law enforcement and achieving greater arrest and conviction rates.

\section{[Received December 2003; accepted November 2004.]}

\section{References}

Aptech Systems, Inc. GAUSS for Windows (Kernel Rev. 5.0.22, GUI Rev. 5.0.15), 2003.

Arthur, J.A. "Socioeconomic Predictors of Crime in Rural Georgia." Criminal Justice Review 16(1991):29-41.

Becker, G.S. "Crime and Punishment: An Economic Approach." Journal of Political Economy 76(1968):169-217.

Bowers, K.J., and S.D. Johnson. "The Stability of Space-Time Clusters of Burglary." British Journal of Criminology 44(2004):55-65.

Brandt, P.T., and J.T. Williams. "A Linear Poisson Autoregressive Model: The Poisson AR(p) Model." Political Analysis 9(2001):164-84. . PESTS Code. Available at http://www.psci. unt.edu/ brandt/pests/pests.htm (downloaded 18 October 2002).

Brandt, P.T., J.T. Williams, B.O. Fordham, and B. Pollins. "Dynamic Modelling for Persistent Event Count Time Series." American Journal of Political Science 44(2000):823-43.

Brotman, B.A., and P. Fox. "The Impact of Economic Conditions on the Incidence of Arson: Comment." Journal of Risk and Insurance 55(1988):751-54.

Burdett, K., R. Lagos, and R. Wright. "Crime, Inequality, and Unemployment." American Economic Review 93(2003):1764-77.

Butry, D.T., J.M. Pye, and J.P. Prestemon. "Prescribed Fire in the Interface: Separating the People from the Trees." In K.W. Outcalt, ed., Proceedings of the 11th Biennial Southern Silvicultural Research Conference. Asheville, NC: U.S. Department of Agriculture, Forest Service General Technical Report SRS-48, 2002, pp. 132-36.

Cameron, S. "The Economics of Crime Deterrence: A Survey of Theory and Evidence." Kyklos 41(1988):301-23.

Cameron, C.A., and P.K. Trivedi. Regression Analysis of Count Data. Cambridge: Cambridge University Press, 1998. 
Carlson, S.M., and R.J. Michalowski. "Crime, Unemployment, and Social Structures of Accumulation: An Inquiry into Historical Contingency." Justice Quarterly 14(1997):209_ 39.

Chang, T.J., M.L. Kavvas, and J.W. Delleur. "Daily Precipitation Modeling by Discrete Autoregressive Moving Average Processes." Water Resources Research 20(1984):565-680.

Corman, H., and H.N. Mocan. "A Time Series Analysis of Crime, Deterrence, and Drug Abuse in New York City." American Economic Review 90(2000):584-604.

Di Tella, R., and E. Schargrodsky. "Do Police Reduce Crime? Estimates Using the Allocation of Police Forces after a Terrorist Attack." American Economic Review 94(2004):115-33.

Donoghue, L.R., and W.A. Main. "Some Factors Influencing Wildfire Occurrence and Measurement of Fire Prevention Effectiveness." Journal of Environmental Management 20(1985):87-96.

EarthInfo, Inc. "NCDC First Order Summary of the Day." Data on CD, 2002.

Eck, J., and E. Maguire. "Have Changes in Policing Reduced Violent Crime? An Assessment of the Evidence." In A. Blumstein and J. Wallman, eds. The Crime Drop in America. New York: Cambridge University Press, 2000, pp. 207-65.

Farrell, G., and K. Pease. "Crime Seasonality: Domestic Disputes and Residential Burglary in Merseyside 1988-90." British Journal of Criminology 34(1994):487-98.

Fisher, F., and D. Nagin. "On the Feasibility of Identifying the Crime Function in a Simultaneous Model of Crime Rates and Sanction Levels." In A. Blumsten, J. Cohen, and D. Nagin, eds. Deterrence and Incapacitation: Estimating the Effects of Criminal Sanctions on Crime Rates. Washington DC: National Academy of Sciences, 1978, pp. 361-99.

Florida Bureau of Economic and Business Research. Long-term Economic Forecast 2001, Vol. 1 and 2 (CD-ROM). Gainesville FL: University of Florida, 2002.

Florida Department of Law Enforcement. "Data on Full-Time Equivalent Officers per County per Year Obtained by Special Request," 2002.

. Total Crime in Florida, 1960-2003. Available at http://www.fdle.state.fl.us/fsac/crime trends/total_index/total_crime.asp (data accessed by authors 7 July 2004).

Gill, A.M., K.R. Christian, P.H.R. Moore, and R.I. Forrester. "Bush Fire Incidence, Fire Hazard and Fuel Reduction Burning." Australian Journal of Ecology 12(1987):299-306.
Gorte, J.K., and R.W. Gorte. "Application of Economic Techniques to Fire Management: A Status Review and Evaluation." USDA Forest Service General Technical Report INT-53. Ogden, UT: USDA Forest Service, 1979.

Gould, E.D., B.A. Weinberg, and D.B. Mustard. "Crime Rates and Local Labor Market Opportunities in the United States: 1979-1997." Review of Economics and Statistics 84(2002):4561.

Greene, W.H. Fixed and Random Effects in Nonlinear Models. Available at http://pages.stern. nyu.edu/ $\sim$ wgreene/panel.pdf (accessed by authors on 29 March 2003).

Grunwald, G., K. Hamza, and R. Hyndman. "Some Properties and Generalizations of NonNegative Bayesian Time Series Models." Journal of the Royal Statistical Society, Series B 59(1997):615-26.

Hall, J.R. U.S. Arson Trends and Patterns. Quincy, MA: National Fire Protection Association, 2000.

Hannon, L. "Criminal Opportunity Theory and the Relationship between Poverty and Property Crime." Sociological Spectrum 22(2002):36381.

Harvey, A.C., and C. Fernandes. "Time Series Models for Count or Qualitative Observations." Journal of Business and Economic Statistics 7(1989):407-17.

Hershbarger, R.A., and R.K. Miller. "The Impact of Economic Conditions on the Incidence of Arson." Journal of Risk Insurance 45(1978):27590.

Jacob, B.A., and L. Lefgren. "Are Idle Hands the Devil's Workshop? Incapacitation, Concentration, and Juvenile Crime." American Economic Review 93(2003):1560-77.

Ji, M., D.W. Behringer, and A. Leetmaa. "An Improved Coupled Model for ENSO Prediction and Implications for Ocean Initialization. Part II: The Coupled Model." Monthly Weather Review 126(1998):1022-34.

Johnson, S.D., and K.J. Bowers. "The Burglary as a Clue to the Future: The Beginnings of Prospective Hot-Spotting." European Journal of Criminology 1(2004):237-55.

Keetch, J.J., and G.M. Byram. A Drought Index for Forest Fire Control. Southeast Forest Experiment Station Research Paper SE-38, Asheville, NC, 1968.

Kent, B., et al. "Social and Economic Issues of the Hayman Fire." In R.T. Graham, ed. Hayman Fire Case Study. Fort Collins, CO: USDA Forest Service, USDA Forest Service General 
Technical Report RMRS-GTR-114 (Revision), 2003, pp. 315-95.

Marvell, T., and C. Moody. "Specification Problems, Police Levels, and Crime Rates." Criminology 34(1996):609-46.

National Climatic Data Center. Summary of the Day. Boulder: EarthInfo, Inc., 2001.

National Oceanic and Atmospheric Administration. El Niño-Southern Oscillation Sea Surface Temperature Measures. Available at ftp://ftp.ncep.noaa.gov/pub/cpc/wd52dg/data/ indices/sstoi.indices (accessed by authors on October 2002).

Neustrom, M.W., and W.M. Norton. "Economic Dislocation and Property Crime." Journal of Criminal Justice 23(1995):29-39.

Prestemon, J.P., J.M. Pye, D.T. Butry, T.P. Holmes, and D.E. Mercer. "Understanding Broad Scale Wildfire Risks in a Human-Dominated Landscape." Forest Science 48(2002):685-93.

Rideout, D.B., and P.N. Omi. "Alternate Expressions for the Economic Theory of Forest Fire Management." Forest Science 36(1990):614-24.

Sapp, A.D., T.G. Huff, G.P. Gary, D.J. Icove. $A$ Motive-Based Offender Analysis of Serial Arsonists. Available at http://www.interfire.org/ features/serialarsonists/Motive_based/cover. htm (accessed by authors on 24 September 2001).

Spillman, T.C., and T.A. Zak. "Arson: An Economic Phenomenon." American Economist 23(1979):37-43.

Surrette, R. "Self-Reported Copycat Crime Among a Population of Serious and Violent Juvenile Offenders." Crime and Delinquency 48(2002):46-69.
Townsley, M., and K. Pease. "Hot Spots and Cold Comfort." Crime Prevention Studies 13(2001):59-69.

Townsley, M., R. Homel, and J. Chaseling. "Infectious Burglaries: A Test of the Near Repeat Hypothesis." British Journal of Criminology 43(2003):615-33.

Tridata Corporation. Arson in the United States. National Fire Data Center Publication FA174, 1997.

United States Department of Commerce, Census Bureau. Small Area Income and Poverty Estimates, State and County Estimates. Available at http://www.census.gov/hhes/www/saipe/ estimatetoc.html (accessed by authors on 3 September 2002).

United States Department of Labor. Local Area Unemployment Statistics. Available at http://www.bls.gov/ (accessed by authors on 31 October 2002).

. Quarterly Census of Employment and Wages: Retail Trade. Available at http://www.bls.gov/ (accessed by authors on 12 July 2004).

Vega Garcia, C., P.M. Woodard, S.J. Titus, W.L. Adamowicz, and B.S. Lee. "A Logit Model for Predicting the Daily Occurrence of Human Caused Forest Fires." International Journal of Wildland Fire 5(1995):101-11.

Viscusi, W.K. "Market Incentives for Criminal Behavior." In R. Freeman and H. Holzer, eds. The Black Youth Employment Crisis. Chicago: University of Chicago Press, 1986, pp. 30146.

Zeger, S.L. "A Regression Model for Time Series of Counts." Biometrika 75(1988):62129. 